\title{
Sucrose concentration and blueberry plant density in temporary immersion systems (TIS)
}

\author{
Ricardo Antonio Ayub ${ }^{1}$, André Belmont Pereira ${ }^{2}$, Jessé Neves dos Santos ${ }^{3}$, \\ Daurimar Mendes da Silva ${ }^{4}$, Isabela Leticia Pessenti ${ }^{5}$
}

\begin{abstract}
The aim was to determine the ideal concentration of sucrose along with the number of plants per container in the face of micropropagation of blueberry under TIS. In the experiment conducted with sucrose concentration $\left(0,10,20\right.$, e $\left.30 \mathrm{~g} \mathrm{~L}^{-1}\right)$, we utilized a WPM medium, taking into account 30 explants per container. For the experiment dealing with blueberry plant density, the same medium with $20 \mathrm{~g} \mathrm{~L}^{-1}$ of sucrose in conjunction with $30,40,50$ and 60 explants per container was used. After 90 days from the installation of the trial, the following response variables were assessed herein: total length of the plant, number of shoots, length of the largest shoot, number of hyperhydric shoots, length of hyperhydric shoots, and number of healthy leaves. Under a sucrose concentration corresponding to $20 \mathrm{~g} \mathrm{~L}^{-1}$ the best possible results were obtained. Survival rates of 22 and $80 \%$ under the influence of both 10 and $20 \mathrm{~g}$ $\mathrm{L}^{-1}$ treatments were reported, pointing out that plants exposed to $20 \mathrm{~g} \mathrm{~L}^{-1}$ treatment were more amenable to acclimatization. Thus, for the micropropagation of blueberry under TIS the use of $20 \mathrm{~g} \mathrm{~L}^{-1}$ sucrose and 60 plants/container comes to being highly recommended to increase yield. Index Terms: Vaccinium ashei Reade; Bioreactor, Micropropagation.
\end{abstract}

\section{Concentração de sacarose e densidade de planta de mirtilo em sistemas de imersão temporária (TIS)}

Corresponding author: rayub@uepg.br

Received: December 24, 2020 Accepted: May 05, 2021

Copyright: All the contents of this journal, except where otherwise noted, is licensed under a Creative Commons Attribution License.

\begin{abstract}
Resumo - O objetivo desta pesquisa foi determinar a concentração ideal de sacarose, juntamente com o número de plantas por recipiente, em face da micropropagação de mirtilo sob TIS. No experimento realizado com concentração de sacarose $\left(0 ; 10 ; 20\right.$, e $\left.30 \mathrm{~g} \mathrm{~L}^{-1}\right)$, foi utilizado um meio Woody Plant Medium (WPM), levando-se em consideração 30 explantes por recipiente. Para o experimento de densidade de plantas de mirtilo, foi utilizado o mesmo meio, com $20 \mathrm{~g} \mathrm{~L}^{-1} \mathrm{de}$ sacarose, em conjunto com 30; 40; 50 e 60 explantes por recipiente. Após 90 dias da instalação do ensaio, as seguintes variáveis de resposta foram avaliadas aqui: comprimento total da planta, número de brotos, comprimento da maior brotação, número de brotos hiperídricos, comprimento de brotos hiperídricos e número de folhas saudáveis. Foram relatadas taxas de sobrevivência de 22 e $80 \%$ sob a influência dos tratamentos com 10 e $20 \mathrm{~g} \mathrm{~L}^{-1}$, apontando que as plantas expostas ao tratamento com $20 \mathrm{~g} \mathrm{~L}^{-1}$ foram mais receptivas à climatização. Assim, a micropropagação de mirtilo sob TIS, $20 \mathrm{~g} \mathrm{~L}^{-1}$ de sacarose e 60 plantas / recipiente passa a ser altamente recomendada para aumentar a produtividade e também para melhorar a qualidade dos frutos, em pomares em escala comercial.
\end{abstract}

Termos para indexação: Vaccinium ashei Reade; Biorreator, Micropropagação.

\footnotetext{
${ }^{1}$ Agronomist, Ph.D, Professor Researcher, State University of Ponta Grossa (UEPG), Ponta Grossa-PR, Brasil. Email: rayub@uepg.br ${ }^{\text {(oRcid }}$ 0000-0003-3240-8417)

${ }^{2}$ Agronomist, PhD, State University of Ponta Grossa, Ponta Grossa-PR, Brazil. E-mail: abelmont@uepg.br(ORCID 0000-0002-1673-9841) ${ }^{3}$ Agronomist, MSc, State University of Ponta Grossa, Ponta Grossa-PR, Brazil. E-mail: jessenevessantos@hotmail.com ${ }^{(0 R C I D}$ 0000-0002-4228-8298) ${ }^{4}$ Agronomist, PhD, State University of Ponta Grossa, Ponta Grossa-PR, Brazil. E-mail: daurims@gmail.com (ORCID 0000-0002-0364-2442) ${ }^{5} \mathrm{PhD}$ Student in Agronomy of State University of Ponta Grossa (UEPG), Ponta Grossa-PR, Brazil. isabelaleticiapessenti@gmail.com ${ }^{\text {(ORCID }}$ 0000-0002-5176-3134)
} 


\section{Introduction}

Blueberry (Vaccinium ashei) is a shrub belonging to Ericaceae family, which is native from Europe and North America and featuring an eccentric flavor along with nutritional properties that cause the fruit to be highly valued all over the world, with 540 thousand tons produced in 2014 agricultural harvest (CANTUARIAS-AVILÉS et al. 2014). Since its introduction in Brazil, such a woody species has been expanding in terms of planted area; however, this increment is restricted to a low viability of seeds (PASQUALINI et al. 2016). Apart from such a particular problem, further drawbacks related to low quality of plantlets, lack of phytosanitary warranty and delays in production might be circumvented by the micropropagation technique.

This technique improves initial performance of the crop in production fields as opposed to plants grown by means of cuttings (SOUZA et al. 2011, DEBNATH et al. 2012, MARINO et al. 2014). Nevertheless, high in vitro atmospheric humidity, low light intensity, high concentration of ethylene (AYUB et al. 2017) along with heterotrophic conditions are conducive to low functionality of the stomata, reduce thickness of the cuticle and also impair photosynthetic system, compromising acclimatization (HAZARIKA 2006, MOHAMED; ALSADON 2010, SILVA et al. 2012).

For blueberry a remarkable alternative lies in the multiplication in bioreactors of temporary immersion systems (TIS), which differently from the conventional system makes use of a liquid medium that provides a more substantial contact between explant and medium in such a way as to better absorption of nutrients and ensure a maximization of crop growth and yield at a given site, apart from allowing for automation of the process by reducing costs plus labor (RODRIGUES et al. 2006, SILVA et al. 2007, TEIXEIRA 2011, GEORGIEV et al. 2014, AYUB et al. 2019).

Therefore, TIS improve the efficiency of the technique by means of air renewal, diminishing gaseous stress and making augmentations at a yield scale quite possible (TEIXEIRA; CID 2014, FLOREZ et al. 2016), leading to reductions in costs with agar and sucrose, since atmospheric air gets into the system (ARAGÓN et al. 2010, RIBEIRO et al. 2016), besides increasing plant density, which in turn culminates in a better reclamation of both space and tissue medium.
In addition to such advantages, TIS allows for entrance of atmospheric air into the system, eliminating toxic gases and also reducing air relative humidity in order to galvanize photosynthesis within an optimal of physiological efficiency. In the face of stimulation of photosynthesis, it is possible to reduce or even eliminate the sucrose used in the tissue medium as a source of carbon (ESCALONA 2003). Some species of blueberry were studied under TIS approach, such as Vaccinium angustifolium (DEBNATH, 2009, DEBNATH, 2011) and other species belonging to the groups of highbush, half-high and hybrids (DEBNATH, 2017). Nevertheless, for blueberry pertaining to the Rabbit-eye group, which encompasses species less tolerant to cold, currently there are no research published dealing with protocols stablished to micropropagation technique under TIS approach.

In view of the aforementioned problem, the aim of the current manuscript was to improve micropropagation of blueberry under TIS by means of the assessment of plant density and ideal sucrose concentration.

\section{Material and methods}

\section{Plant Material}

Blueberry (Vaccinium ashei Reade) previously cultivated in vitro at a solid medium WPM (LLOYD;MCCOWN 1980) supplemented with $0.1 \mathrm{~g} \mathrm{~L}^{-1}$ of myo-inositol, $30 \mathrm{~g} \mathrm{~L}^{-1}$ of sucrose $6 \mathrm{~g} \mathrm{~L}^{-1}$ of agar and 5 $\mathrm{mg} \mathrm{L}^{-1}$ of 2iP (N6-(2-Isopentenyl) adenine) was used in the experiment. Stakes of $1.5 \mathrm{~cm}$-length along with two buds were employed as explants. The $\mathrm{pH}$ was adjusted to 5.0. After 90 days such stakes were utilized for the installation of the trial.

\section{Temporary Immersion Systems - TIS}

A doubled-container system with one designed for the explant and another one for a liquid tissue culture featured the TIS under scrutiny, $90 \mathrm{~mL}$ of medium at issue was transferred within a 4-hour time period among containers, which remained in the container with explants for 20 seconds. Shortly after culture medium was placed in the container the explants were autoclaved at $120^{\circ} \mathrm{C}$ for 2 minutes before the installation of the experiment in a laminar flux chamber. The TIS conditions follow the standards reported by Ayub et al. (2019). 


\section{Experiment 1: Sucrose concentration}

Under TIS conditions, 4 pair of $500 \mathrm{~mL}$-containers were used to test 4 concentrations of sucrose: $0,10,20$ and $30 \mathrm{~g} \mathrm{~L}^{-1}$. The liquid medium WPM was supplemented with $0.1 \mathrm{~g} \mathrm{~L}^{-1}$ of inositol plus sucrose, $5.0 \mathrm{mg} \mathrm{L}^{-1}$ of $2 \mathrm{iP}$ and $\mathrm{pH}$ adjusted to 5.0 .30 blueberry explants of $1.5 \mathrm{~cm}$ length were added to containers fixated into phenolic foam, having been assessed after 90 days the following response variables: total length of the plant, shoot length, hyperhydric shoot length, total number of shoots, total number of hyperhydric shoots, overall of healthy shoots, total number of leaves, number of hyperhydric leaves, overall number of dead leaves, overall number of healthy leaves, and fresh weight of the plant.

\section{Experiment 2: Plant acclimatization}

In order to assess survival throughout acclimatization at 30 days, an experiment set up under a completely randomized $2 \times 2$ factorial experimental design has been carried out. For such, blueberry plants from plots subjected to treatments of 10 and $20 \mathrm{~g} \mathrm{~L}^{-1}$ of sucrose encompassing a bigger number of plants amenable to acclimatization along with two distinct sites for it were taken into account in the current study. An acclimatization chamber with relative humidity fluctuations ranging from 75 to $90 \%$ and glasses covered with plastics conditioned to an air relative humidity threshold above $90 \%$ turned out to be the controlled environment under which the experiment has been conducted with four replications for each treatment adopted herein (Figure 1).

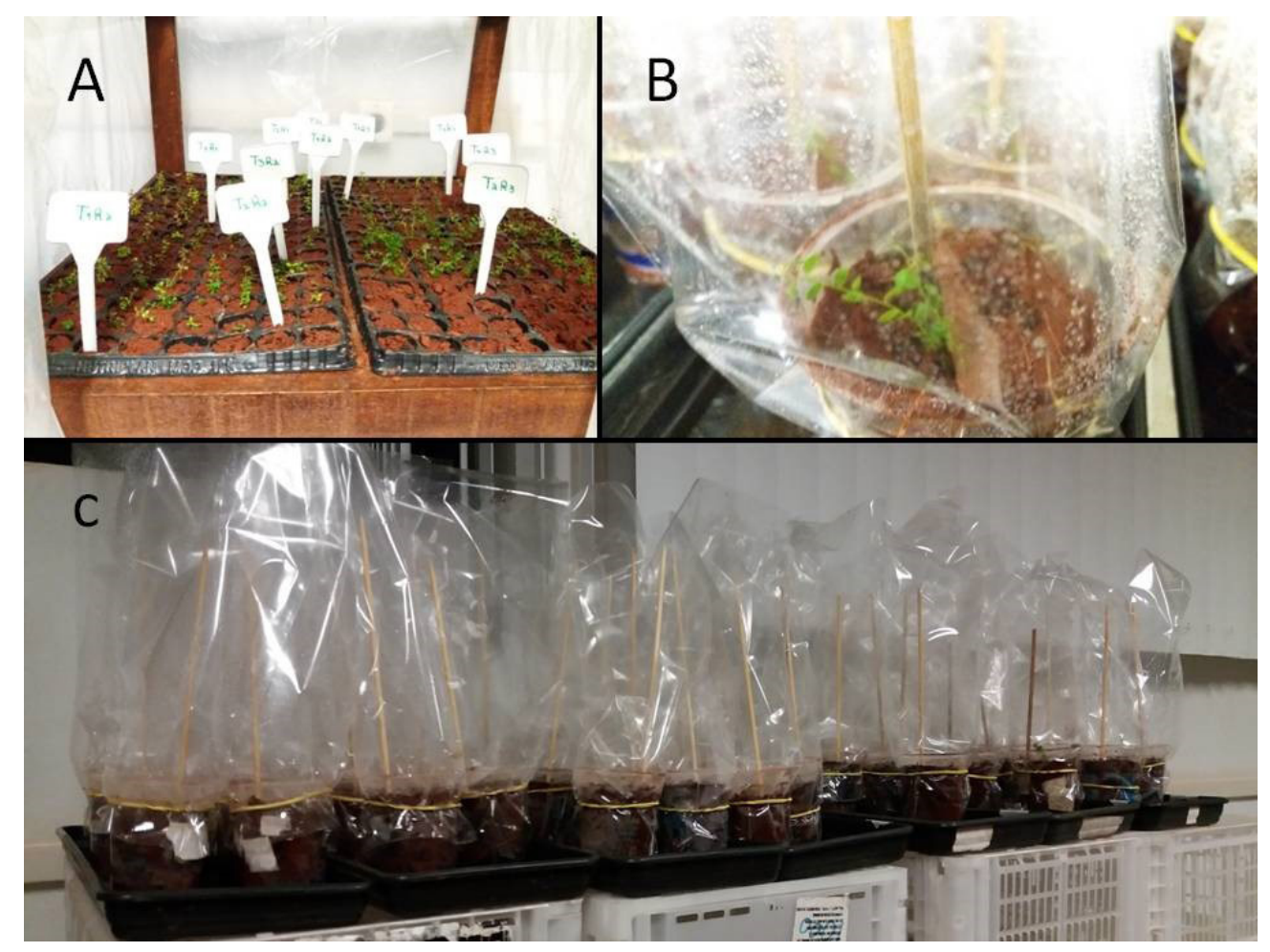

Figure 1. Acclimatization experiment of blueberry. A - Acclimatization chamber. B - plastic cup.

\section{Experiment 3: Plant density}

In light of TIS approach, four pair of containers were used to test four plant densities: 30, 40, 50 and 60 . The liquid medium (WPM) was supplemented with 0.1 $\mathrm{g} \mathrm{L}^{-1}$ of inositol, $30 \mathrm{~g} \mathrm{~L}^{-1}$ of sucrose, $5.0 \mathrm{mg} \mathrm{L}^{-1}$ of $2 \mathrm{iP}$ and $\mathrm{pH}$ adjusted to 5.0. In each single container $(500-\mathrm{mL}$ capacity) blueberry explants of $1.5 \mathrm{~cm}$-length were fixated in phenolic foam and after 90 days the following response variables were evaluated: total length of the plant, shoot length, total number of shoots, total number of leaves, overall number of dead leaves, fresh weight of the plant, and number of acclimatized plants.

\section{Growth room}

The experiments were conducted at a growth room set up to $25 \pm 2{ }^{\circ} \mathrm{C}$-air temperature, 16-hour photoperiod and a photon flux density corresponding to $27 \mu \mathrm{mol} \mathrm{m}^{-2} \mathrm{~s}^{-1}$.

\section{Statistic experimental design}

The experiments were carried out under completely randomized experimental design, taking into consideration four replications. Experimental data were submitted to analysis of variance (ANOVA) along with application of Shapiro Wilk and Tukey tests, as well as to a polynomial regression study by means of the statistical program Sisvar (FERREIRA, 2014). The maximum point was calculated as a function of the derivate of the regression equations obtained. 


\section{Results and discussion}

The best growth performance of the plants under TIS approach has been obtained at a concentration of 15 $\mathrm{g} \mathrm{L}^{-1}$ of sucrose, in compliance with the inflexion point of the regression curve (Figures 2, 3, 4, and 5). (Fig. 2:
$\hat{\mathrm{Y}}_{\text {Total length }}=17.357+2.1986 \mathrm{X}-0.072 \mathrm{X}^{2)}$. However, under the influence of such a treatment it was possible to notice a more pronounced incidence of hyperhydricity $(10 \mathrm{~g}$ $\mathrm{L}^{-1}$ ) (Figures $6 \mathrm{~A}, \mathrm{~B}$ ) on both shoots and leaves, which comes to being quite undesirable.

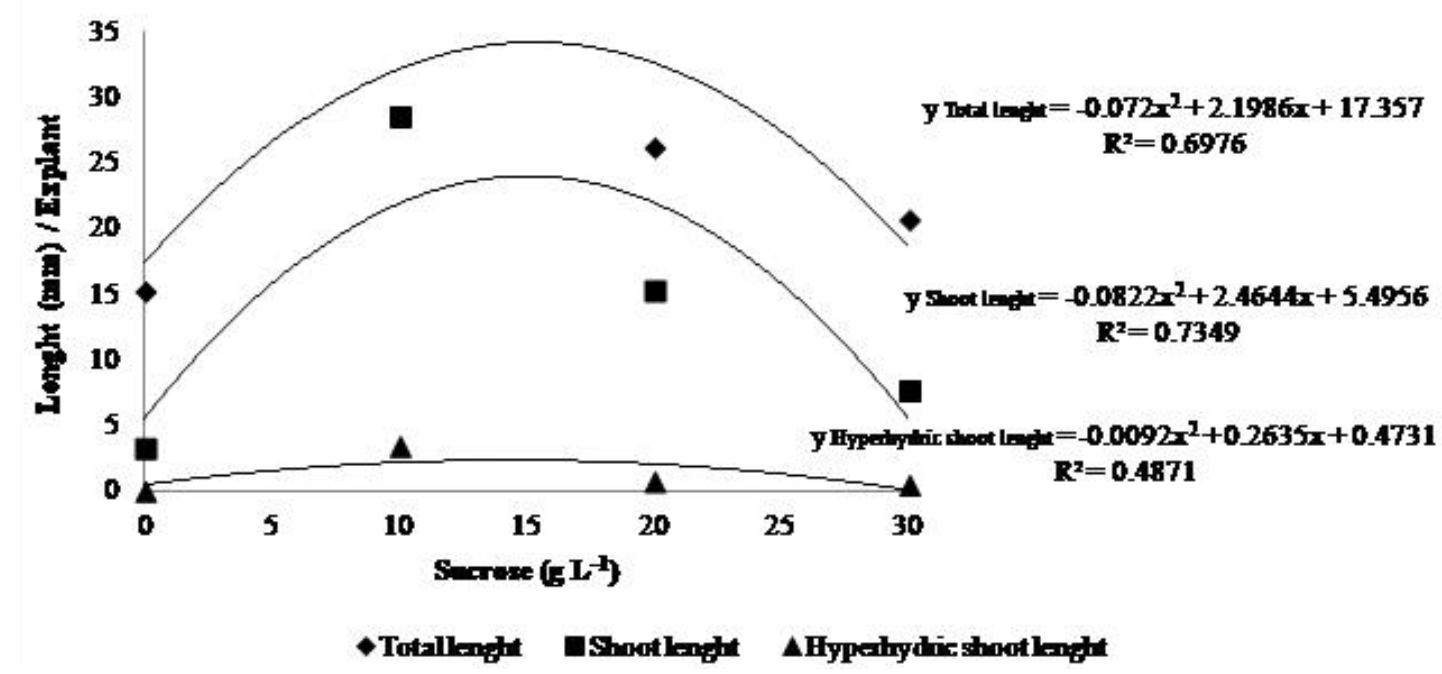

Figure 2. Influence of sucrose on plant total length, shoot length and hyperhydric shoot length of blueberry plants cultivated under TIS. Correct on all models.

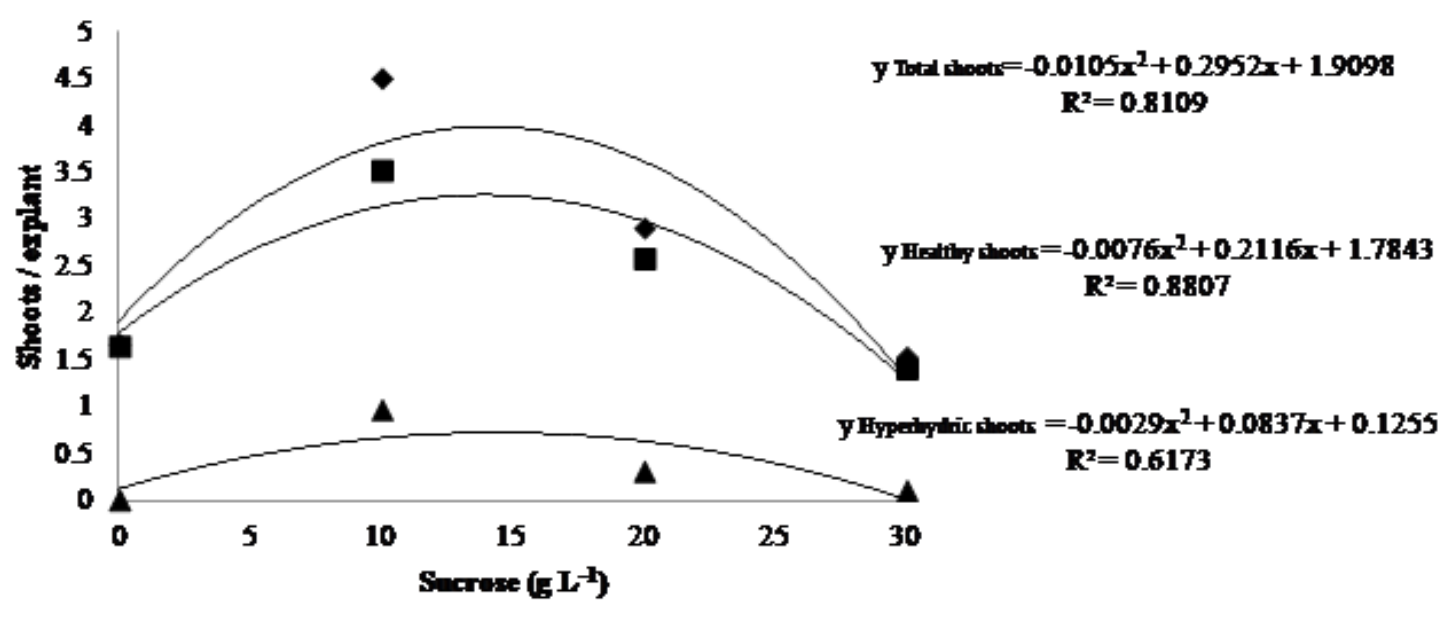

- Totalshoots DHealihy shoots AHypenydirshoots

Figure 3. Influence of sucrose on the number of total shoots, healthy shoots and hyperhydric shoots per explant of blueberry cultivated under TIS. 


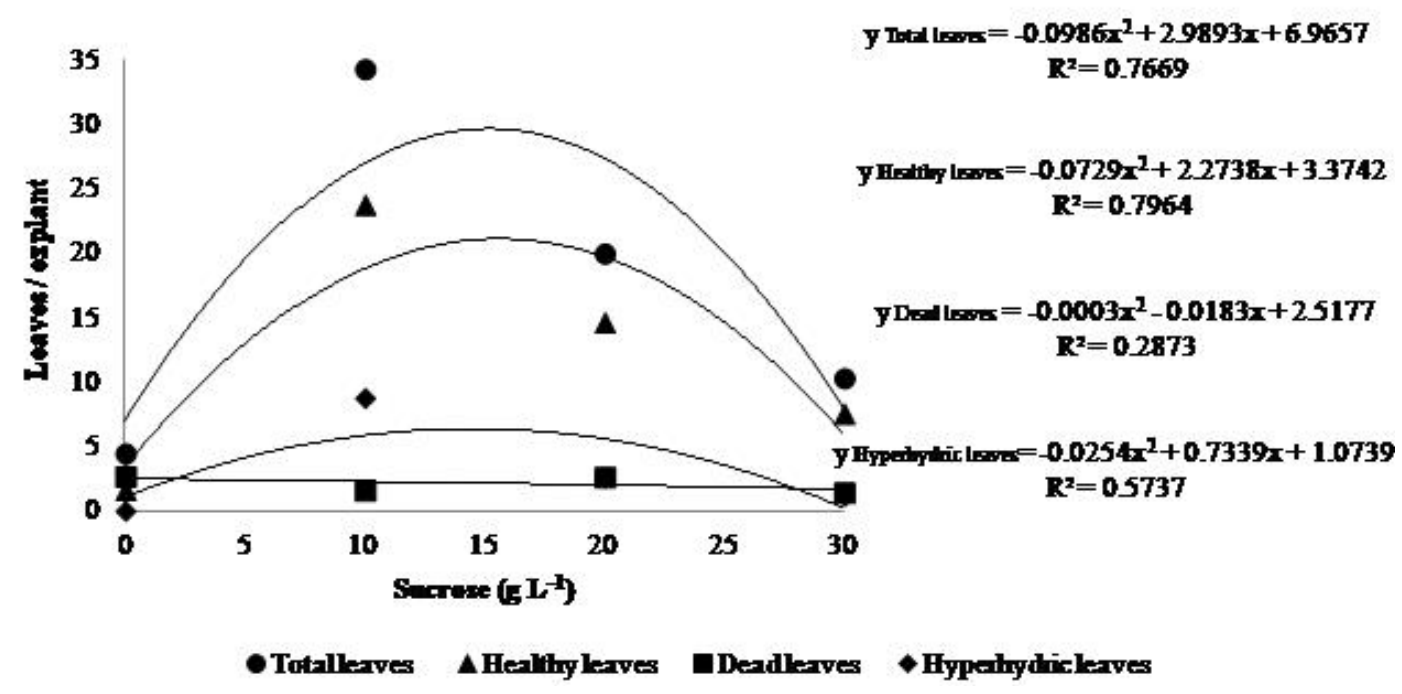

Figure 4. Influence of sucrose on the total amount of leaves, healthy leaves, dead leaves and hyperhydric leaves per explant of blueberry cultivated under TIS.

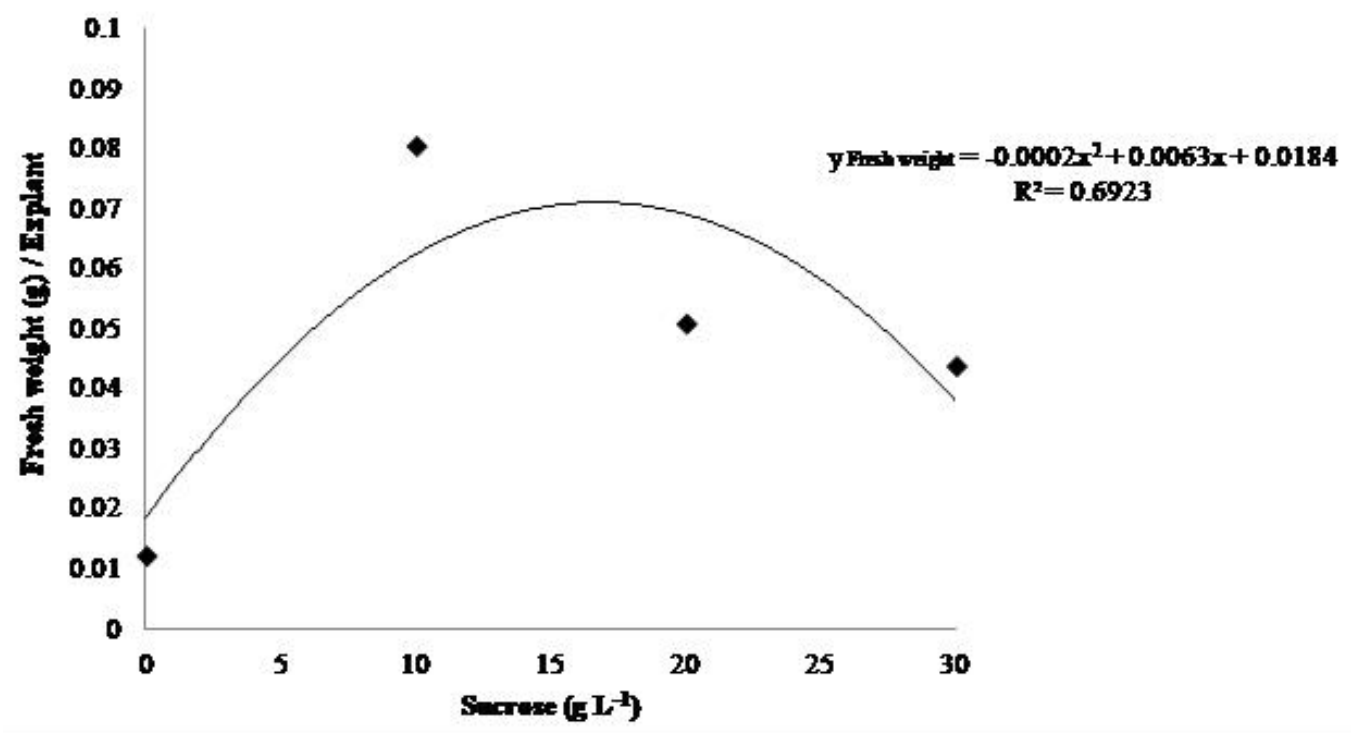

Figure 5. Sucrose influence on blueberry fresh weight per explant cultivated under TIS.

Throughout acclimatization, we observed that in view of variable air relative humidity thresholds the $10 \mathrm{~g} \mathrm{~L}^{-1}$ of sucrose treatment was conducive to a $22 \%$ survival, whereas blueberry plants exposed to the $20 \mathrm{~g}$ $\mathrm{L}^{-1}$ of sucrose treatment resulted in an $80 \%$ survival rate (Figure 7). Conversely, acclimatized plants at constant relative humidity levels did not show statistical differences among different concentrations of sucrose (Figure 7).
At the plant density experiment, statistical discrepancies were not evidenced for the following response variables: total length of the plant $(18.73 \mathrm{~mm})$, number of shoots $(1.73)$, shoot length $(9.4 \mathrm{~mm})$, total number of leaves (9.63), overall number of dead leaves (1.1) for each single explant. However, with regards to fresh mass and acclimatization survival the experimental data better fitted a quadratic function in statistical terms.

Increases in total number of plants caused fresh mass per explant to reduce up to 51.66 plantlets per container (Figure 8A), as well as survival percentage to drop up to 57.11 plantlets per container (Figure 8B). From such a point on, rises in overall number of plants favored augmentation in fresh mass of the plant and also in survival rates throughout acclimatization. 


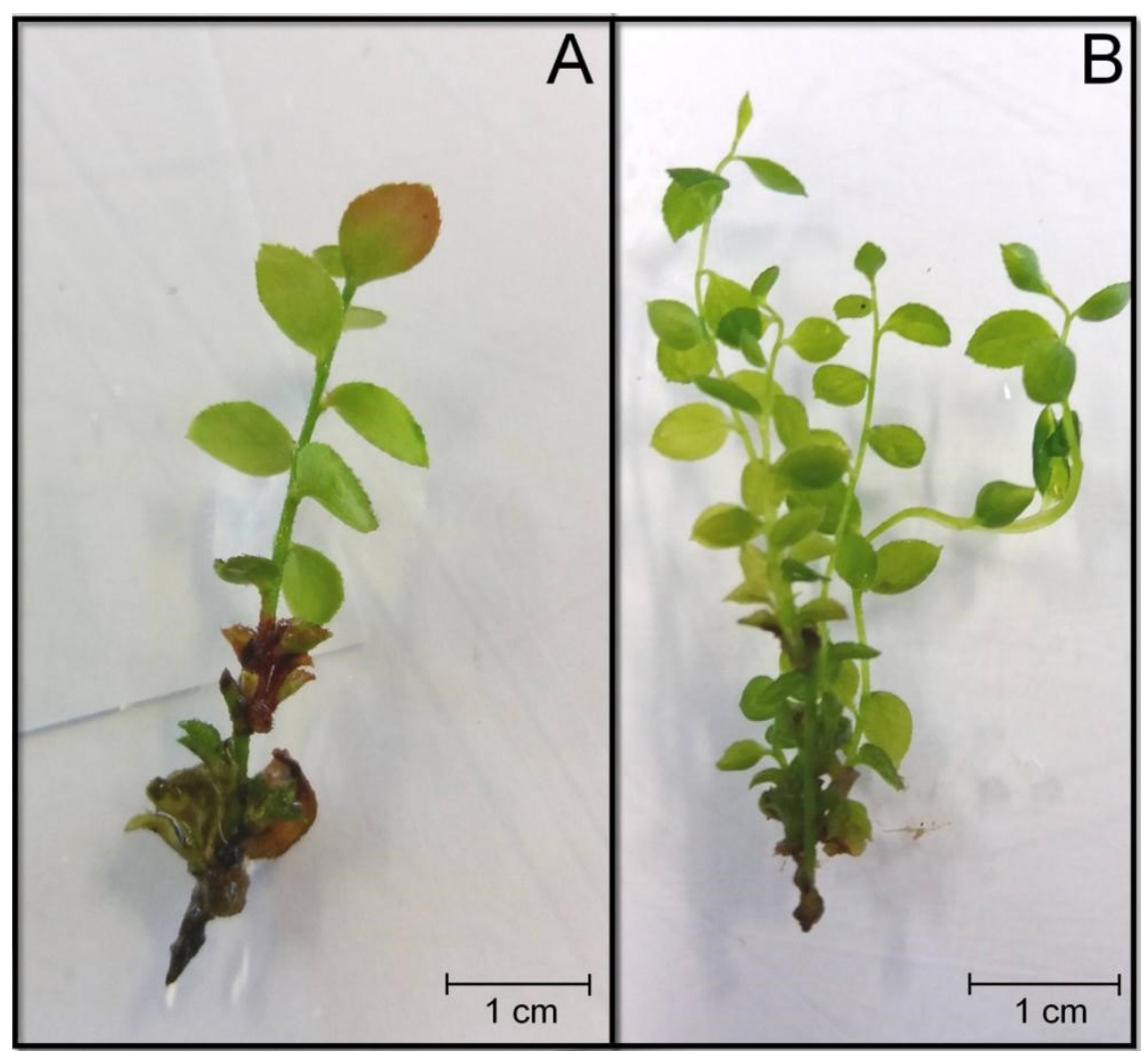

Figure 6. Blueberry healthy shoots obtained with $20 \mathrm{~g} \mathrm{~L}^{-1}$ of sucrose (A) compared with hyperhydric shoots obtained with $10 \mathrm{~g} \mathrm{~L}^{-1}$ sucrose (B) grown under TIS.

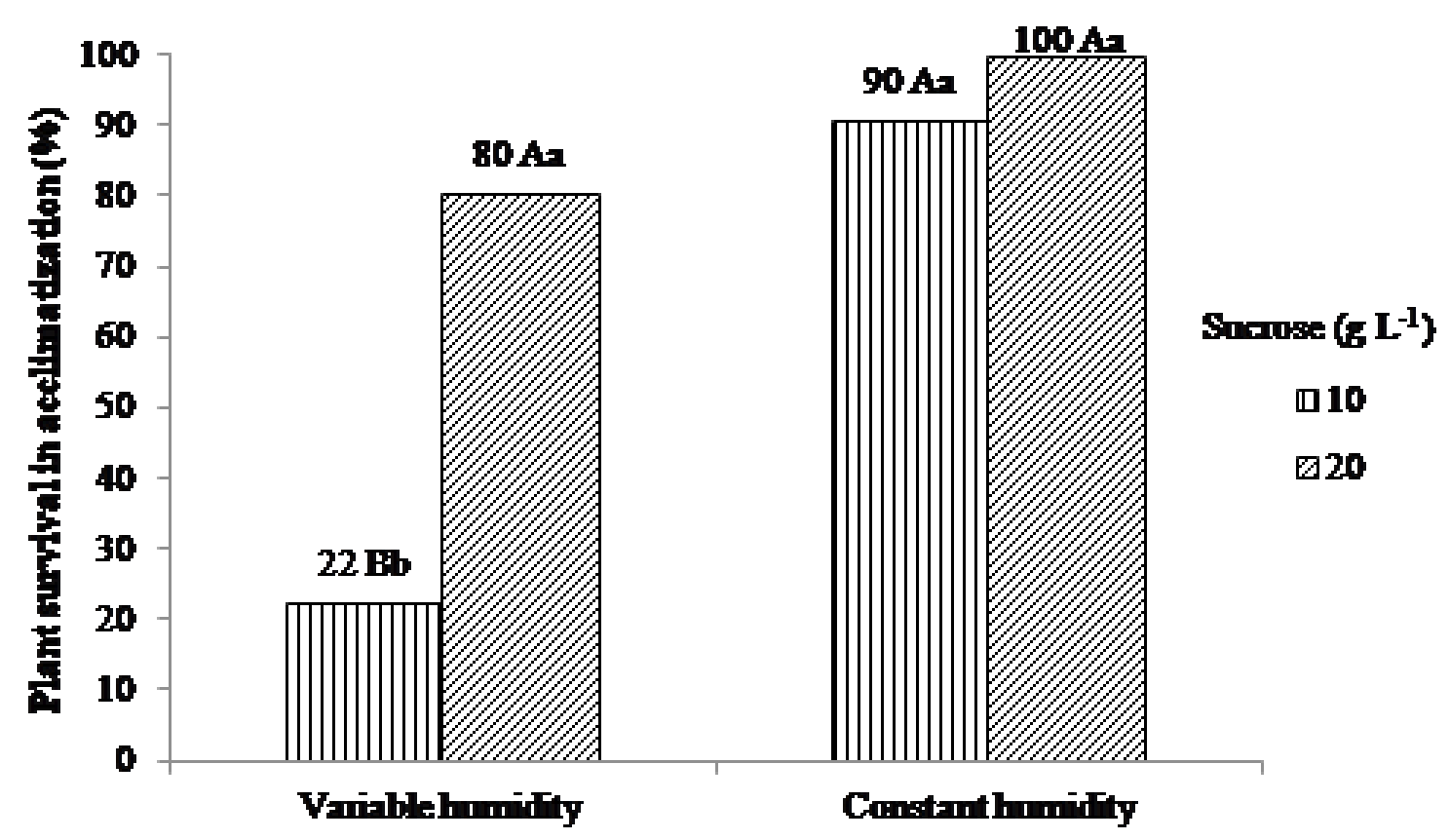

Figure 7. Influence of sucrose concentration on blueberry plant survival throughout acclimatization. Means followed by the same lowercase letters between sucrose concentration and the same uppercase letters between relative humidity do not differ statistically among treatments by the Tukey test $(\mathrm{p} \leq 0.05)$. 


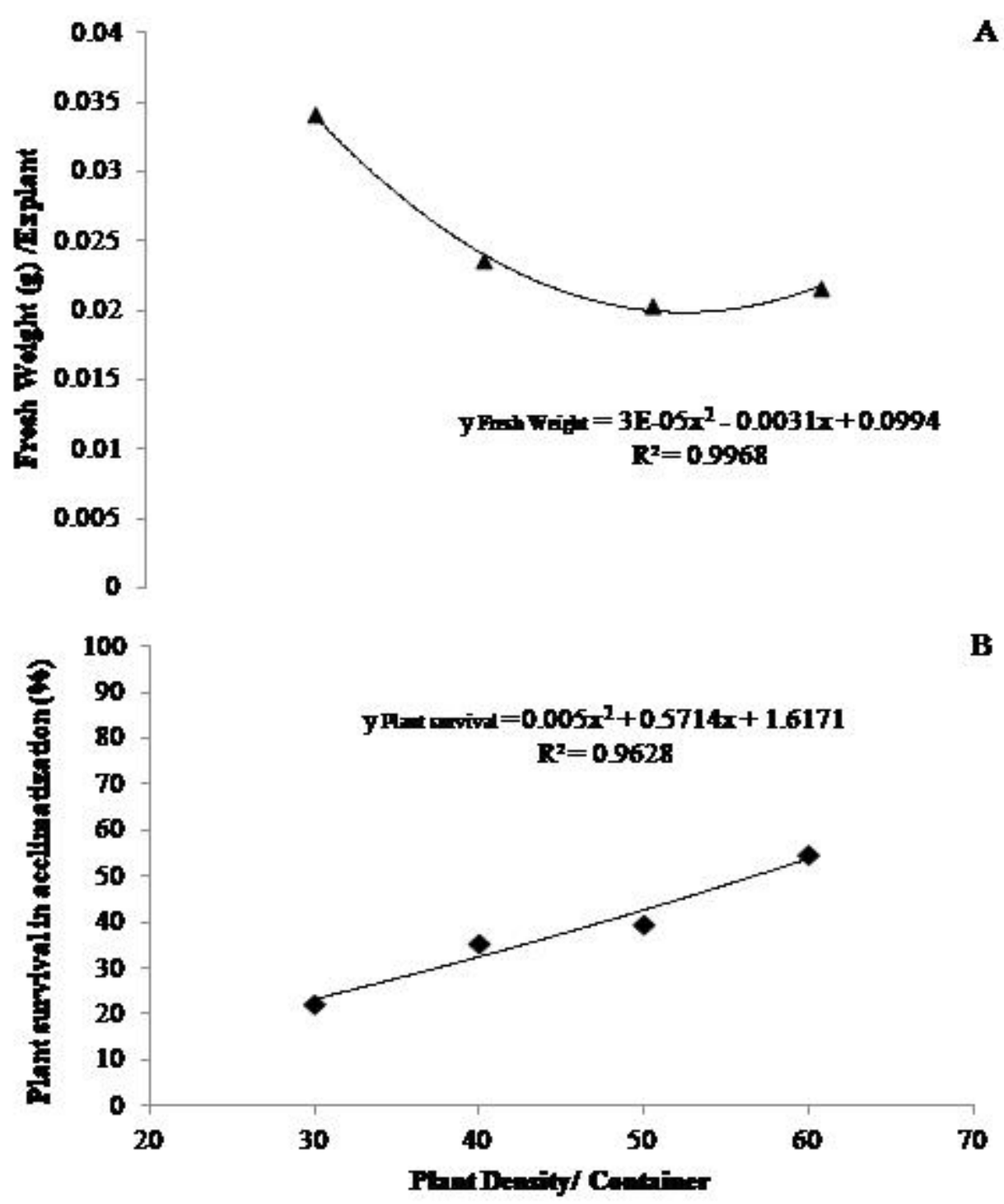

Figure 8. Plant density influence on fresh weight per explant under TIS (A) and plant survival through acclimatization (B).

The estimated value of $15 \mathrm{~g} \mathrm{~L}^{-1}$ considered to be the best sucrose concentration to be borne in mind was quite similar to that obtained by Cao et al. (2003) when it comes to micropropagation technique to be applied to Vaccinium Corymbosum L. cv. Duke. The $10 \mathrm{~g} \mathrm{~L}^{-1}$ sucrose concentration above providing the best averages in light of TIS was the one conducive to the lowest survival rates under acclimatization conditions. The usage of the liquid medium WPM might favor hyperhydration of plant tissues, galvanizing intensity of such physiological disorder.

It is well known in the literature that adequation of concentration of components, such as sucrose turns out to be pivotal to avoid hyperhydricity and also increase survival of plants throughout acclimatization, mainly because such a disturb seems to be linked to low ex vitro survival rates (ROJAS-MARTÍNEZ et al. 2010, DRIES et al. 2013, RAMÍREZ-MOSQUEDA et al. 2016). Hyperhydricity was also similarly reported by Tetsumura et al. (2008), who examined the effects of different plant tissue culture types on micropropagation of $V$. corymbosum e $V$. virgatum, from which "Berkeley" cultivar when grown in MS mediums culminated in the highest incidence of hyperhydric shoots.

In view of such a problem, the more the production system approaches to the natural environmental conditions the better acclimatization of plants will be evidenced so that losses during critical phenological stage of the crop might be reduced. The hyperhydric plants are to be more sensitive to environmental stress and to rapid dehydration. Thus, under a small number of plants per container hyperhydricity itself impairs development and acclimatization of blueberry plantlets. 
On the other hand, plants grown under a sucrose concentration corresponding to $20 \mathrm{~g} \mathrm{~L}^{-1}$ showed the highest survival rates $(80 \%)$ in conjunction with the best acclimatization possibly garnered. Our outcomes corroborate the findings reported by Debnath (2017), which highlighted that a survival rate ranging from 80 to $90 \%$ throughout acclimatization was obtained whenever plants were grown under TIS and stationary systems, respectively. Survival of plants is favored by means of TIS because considerably improves leaf thickness and also functionality of stomata (BRAGA, et al. 2010).

\section{Conclusions}

The $10 \mathrm{~g} \mathrm{~L}^{-1}$ sucrose concentration clearly promoted formation of hyperhydricity, reducing in turn survival throughout acclimatization, whereas both the $20 \mathrm{~g} \mathrm{~L}^{-1}$ coupled with 60 plants per container did favor survival rates. Further scientific investigations are supposed to be conducted in order to examine the impact of different plant density levels on blueberry micropropagation under TIS approach.

\section{Acknowlegments}

The authors are very grateful to Coordenação de Aperfeiçoamento de Pessoal de Nível Superior (CAPES), Conselho Nacional de Desenvolvimento Científico e Tecnológico (CNPq) and Universidade Estadual de Ponta Grossa (UEPG) for the logistical and financial supports provided to the current research.

\section{References}

ARAGÓN, C.E.; ESCALONA, M.; RODRIGUEZ, R.; CAÑAL, M.J.; CAPOTE, I.; PINA, D.; GONZÁLEZOLMEDO, J. Effect of sucrose, light, and carbon dioxide on plantain micropropagation in temporary immersion bioreactors. In Vitro Cellular Developmental Biology

- Plant, Heidelberg, v.46. n.1, p.89-94, 2010.

AYUB, R.A.; SANTOS, J.N. dos; BOTELHO, R.V. Blueberry (Vaccinium ashei Reade) cv. Brightwell in vitro establishment with silver thiosulfate. Plant Cell Culture \& Micropropagation, Lavras, v. 13, n.1, p.1-6, 2017.

AYUB, R.A.; SANTOS, J.N. dos; ZANROLENSI JUNIOR, L.A.; SILVA, D.M.; CARVALHO, T.C.; GRIMALDI, F. Sucrose concentration and volume of liquid medium on the in vitro growth and development of blackberry cv. Tupy in temporary immersion systems. Ciência e Agrotecnologia, Lavras, v.43, n.1, 2019.
BRAGA, F.T. Natural light and seal systems on in vitro propagation of chrysanthemum cv. rage: anatomical and physiological alterations. Plant Cell Culture \& Micropropagation, Lavras, v.6, n.2, p.83-89, 2010.

CANTUARIA-AVILÉS, T.; SILVA, S.R.; MEDINA, R.B.; MORAES, A.F.G.; ALBERTI, M.F. Variety introduction of low chilling demand in the state of São Paulo. Revista Brasileira de Frutultura, Jaboticabal, v.36, n.1, p.139147, 2014

CAO, X.; FORDHAM, I.; DOUGLASS, L.; HAMMERSCHLAG, F. Sucrose level influences micropropagation and gene delivery into leaves from in vitro propagated, highbush blueberry shoots. Plant Cell, Tissue and Organ Culture, Dordrecht, v.75, n.3, p.255259, 2003.

DEBNATH, S.C. A scale-up system for lowbush blueberry micropropagation using a bioreactor. HortScience, Alexandria, v.44, n.7, p.1962-1966. 2009.

DEBNATH, S.C. Bioreactors and molecular analysis in berry crop micropropagation - A review. Canadian Journal of Plant Science, Ottawa, v.91, n.1. p.147-157, 2011.

DEBNATH, S.C. Temporary immersion and stationary bioreactors for mass propagation of true-to-type highbush, half-high, and hybrid blueberries (Vacciunium spp.). Journal of Horticultural Science and Biotechnology, Abingdon, v.92, n.1, p.72-80, 2017.

DEBNATH, S.C.; VYAS, P.; GOYALI, J.C.; IGAMBERDIEV, A.U. Morphological and molecular analyses in micropropagated berry plants acclimatized under ex vitro condition. Canadian Journal of Plant Science, Ottawa, v.92, n.6, p.1065-1073, 2012.

DRIES, N. V. D.; GIANNI, S.; KRENS, F.A.; CZEREDNIK, A. Flooding of the apoplast is a key factor in the development of hyperhydricity. Journal of Experimental Botany., Oxford, v.64, n.16, p.5221-5230, 2013.

ESCALONA, M.; SAMSON, G.; BORROTO, C.; DESJARDINS, Y. Physiology of effects of temporary immersion bioreactors on micropropagated pineapple plantlets. In Vitro Cellular Developmental Biology Plant, Heidelberg, v.39, n.6, p.651-656, 2003. 
FERREIRA, D.F. Sisvar - a guide for its bootstrap procedures in multiple comparisons. Ciência e Agrotecnologia, Lavras, v.38, n.2, p.109-112, 2014.

FLOREZ, S.L; CURTIS, M.S.; SHAW, S.E.; HAMAKER, N.K.; LARSEN, J.S.; CURTIS, W.R. A temporary immersio plant propaatn bioctor with dcoupled gas and liquid flows for enhanced control of gas phase. Biotechnology Progress, Washington, v.32, n.2, p.337345, 2016.

GEORGIEV, V.; SCHUMANN, A.; PAVLOV, A.; BLEY, T. Temporary immersion systems in plant biotechnology. Engineering in Life Sciences, Weinheim, v.14, n.6, p.607$621,2014$.

HAZARIKA, B.N. Morpho-physiological disorders in in vitro culture of plant. Scientia Horticulturae, Wageningen, v.108, n.2, p.105-120, 2006.

LLOYD, G.; MCCOWN, B. Commercially-feasible micropropagation of mountain laurel, Kalmia latifolia, by use of shoot-tip culture. Combined Proceedings International Plant Propagators Society, Bellefonte, v.30, n.1, p.421- 427, 1980.

MARINO, S.R.; WILLIAMSON, J.G.; OLMSTEAD, J.W.; HARMON, P.F. Vegetative growth of three southern highbush blueberry cultivars obtained from micropropagation and softwood cuttings in two Florida locations. HortScience, Alexandria, v.49, n.5, p.556-561, 2014.

MOHAMED, M.A.M.,; ALSADON, A.A. Influence of ventilation and sucrose on growth and leaf anatomy of micropropagated potato plantlets. Scientia Horticulturae, Wageningen, v.123, n.3, p.295-300., 2010.

PASQUALINI, A.P. de A.; NEVES, J.; AYUB, R.A. Behavior and viability of blueberry seeds through germination and tetrazolium test. Advances in Bioscience and Biotecology, Wuhan, v.7, n.1, p.1-18, 2016.

RAMÍREZ-MOSQUEDA, M.A. Micropropagation of Stevia rebaudiana Bert. in temporary immersion systems and evaluation of genetic fidelity. South African Journal of Botany, Amsterdam, v.106, n.1, p.238-243, 2016.

RIBEIRO, A. dos S.; TORMEN, G.E.; FIGUEIREDO, G.C.R.; RONDON, A.J. In vitro bamboo cultivation in different spread systems. Nativa, Sinop, v.4. n.1, p.15$18,2016$.
RODRIGUES, P.H.V.; TEIXEIRA, F.M.; LIMA, A.M.L.P.; AMBROSANO, G.M.B. Propagation of heliconia plantlets in temporarily immersion bioreactor. Bragantia. 65 (1): 29-35. 2006.

ROJAS-MARTÍNEZ, L.; KLERK, G.J. de; VISSER, R.G.F. The hyperhydricity syndrome: waterlogging of plant tissues as a major cause. Propagation of Ornamental Plants, Sofia, v.10, n.4, p.169-175, 2010.

SILVA, A.B. s; PASQUAL, M.; CASTRO, E.M. de; RAMOS, J.D.; BRAGA, F.T.; ARAUJO, A.G. de. Natural light, sucrose and growth regulators on leaf anatomy and in vitro growth of micropropagated pineapple. Plant Cell Culture \& Micropropagation, Lavras, v.8, n.12, p.1-9, 2012.

SILVA, A.B. da; PASQUAL, M.; TEIXEIRA, J,B.; ARAUJO, A.G. de. Micropropagation methods of pineapple. Pesquisa Agropecuária Brasileira, Brasília, DF, v.42, n.9, p.1257-1260, 2007.

SOUZA, A.L.K. de; SCHUCH, M.W.; ANTUNES, L.E.C.; SCHMITZ, J.D.; PASA, M. Da S.; CAMARGO, S.S.; CARRA, B. Performance of blueberry seedlings obtained by micropropagation or cutting. Pesquisa Agropecuária Brasileira, Brasília, DF, v.46 (8): 868874, 2011.

TEIXEIRA, J. B. Biorreator de imersão temporária - O futuro da produção industrial de plantas in vitro. In: GERALD, L.T.S. Biofábrica de plantas: produção industrial de plantas in vitro. São Paulo: Antiqua, 2011. p.34-49.

TEIXEIRA, J.B.; CID, L.P.B. Biorreatores para produção de mudas em larga escala. In: CID, L.P.B. Cultivo in vitro de plantas. 3.ed. Brasília (DF): EMBRAPA, 2014. p.159-178.

TETSUMURA, T.; MATSUMOTO, Y.; SATO, M.; HOMSHO, C.; YAMASHITA, K.; KOMATSU, H.; SUGIMOTO, Y.; KUNITAKE, H. Evaluation of basal media for micropropagation of four highbush blueberry cultivars. Scientia Horticulturae, Wageningen, v.119, n.1, p.72-74, 2008. 